\title{
Challenges of Economic Growth, Poverty and Development: Why Are the Millennium Development Goals (MDGs) not Fair to Sub-Saharan Africa?
}

\author{
Kanayo Ogujiuba ${ }^{1} \&$ Fadila Jumare $^{2}$ \\ ${ }^{1}$ National Institute for Legislative Studies (NILS), Abuja- Nigeria and Affiliated with the Department of \\ Statistics and Population Studies-University of Western Cape; Cape Town-South Africa \\ ${ }^{2}$ National Institute for Legislative Studies Abuja, Nigeria \\ Correspondence: Kanayo Ogujiuba, National Institute for Legislative Studies (NILS), Abuja- Nigeria and \\ Affiliated with the Department of Statistics and Population Studies-University of Western Cape, Cape \\ Town-South Africa. E-mail: kannyog@gmail.com
}

Received: September 6, 2012 Accepted: November 8, 2012 Online Published: November 27, 2012

doi:10.5539/jsd.v5n12p52

URL: http://dx.doi.org/10.5539/jsd.v5n12p52

\begin{abstract}
Sub-Saharan African countries report high levels of growth and GDP per capita and yet they are unable to achieve the Millennium Development Goals (MDGs) such as quality education and health. The paper argued that GDP might not be sufficient for measuring development because the funds obtained may not necessarily be used to improve the quality of life of worse off communities. Even with a constituent level of GDP, the problem of poverty and underdevelopment is becoming more intractable in Sub-Saharan Africa. This paper focused on the Challenges facing Sub-Saharan African countries in achieving the Millennium Development Goals (MDGs). This was discussed after revealing growth in GDP and inequality trends in Sub-Saharan Africa. Using examples from countries like Nigeria, it is evident that many countries in Sub-Saharan Africa are unlikely to achieve their MDG targets due to persistence of poverty and other challenges such as corruption and mal-administration of funds. Moreover, the required growth to substantially reduce poverty is too high by international standards. The paper concluded by concurring with the view that redistribution of the growth increment of income is more likely to be effective in reducing poverty than growth in GDP alone. Therefore while growth in GDP may be prone to poverty reduction, it should be complemented with policies to ensure investment and broad participation, reduce violence, root out corruption and increase investment in infrastructure. The paper recommends that countries' development strategies must take into consideration national realities in each country rather than adopting targets and policies from the western world.
\end{abstract}

Keywords: development, growth, poverty

\section{Introduction}

In September 2000, 147 Heads of states met at the United Nations (UN) head quarters in New York to resolve the most pressing problems of humanity and nature (Attaran, 2005) which include poverty, education, gender and health issues. They expressed their commitment by setting numerical targets and deadlines to measure performance. These are known as the Millenium Development Goals (MDGs) with a wide range of topics including Education, Gender, Health and poverty. Modernists view MDGs as a blueprint for transformation and development. Peet and Hartwick (1999) cite that development is measured by the Gross Domestic Product (GDP) and Gross National Product (GNP), measures of economic growth which assume that development is attained if a certain level of economic growth is reached. By using the GDP and GNP, the World Bank and UN agencies have established that most Sub-Saharan African countries are unlikely to achieve the MDGs by 2015 as stipulated in their summits. For example the UN millennium report, (2005) notes that the picture in Sub-Saharan Africa is not optimistic. Other authors including Easterly (2008) and Attaran (2005) concur with this view but question how the lack of progress is being measured. They contend that most of the indicators used to measure the MDGs are insufficient and depend on unreliable or unavailable data. This contributes to the perception of Africa as "off track" in achieving the MDGs when in fact it could have been determined from the on-set that they will not achieve the goals. 
The challenges faced by African countries in achieving MDGs are not purely economic or related to growth in GDP. There are also political and governance issues involved in reducing progress made by African countries. Some MDG critics posit that donor's aid or debt relief, corruption and other necessary disasters should be blamed for the failure to achieve MDGs. For instance Clemens et al. (2007) argue that it is the limitations of aid and other policies that hinder the achievement of MDGs. Other critics consider MDGs as well intentioned but poorly thought through, thus distracting attention from more appropriate targets and more effective policies and actions (Hulme, 2009).

The focus of this paper is not to underestimate the importance of high GDP levels for attainment of MDG's. Rather it provides an analysis of the MDGs in relation to the paradox of economic growth and poverty reduction. In the process, each of the MDGs was discussed in conjunction with some of the challenges facing Sub-Saharan African countries in achieving them.

\subsection{Theoretical Foundation of MDGs}

Third world elites are understood to be guided by western models thus adopting and adapting its technology, assimilating its values and patterns of action as well as importing its financial industrial and educational institutions. In return, they gain foreign aid and overseas business investments which serve as important channels for the transmission of western values (Valenzuela, 1978). Several theories have been used to explain the rationales behind these practices as well as certain development policies such as the MDGs adopted by International Financial Institutions. Of particular relevance to this paper is modernization theory. This is a functionalist and evolutionary approach in the development and social sciences discipline, which maintains that countries are autonomous units that develop through stages and transform from traditional societies to modern forms (Fangjun, 2009). The theory stipulates that non western societies would only attain the stage of being developed if they acquire the instrumental rationalities of western societies (Dibua, 2006). From observations of trends towards urbanization and industrialization in Europe and North America, Karl Max, Emile Durkheim and Max Weber became original tenets of modernization theory. They made heuristic distinctions between tradition and modernity (Wheeler, 2005). Schuurman (2000) notes modernization theory's unconditional belief in the concept of progress. By the 1930s, the focus of modernization theory shifted to the United States and Talcott Parsons became the leading scholar. Parsons developed a blue print for less developed societies by looking at the way of life of Europeans and Americans (Wheeler, 2005). Walt Witman Rostow (1968) and other scholars on modernization theory lobbied for and formulated United States policies on development assistance such as military assistance in the context of the cold war. While Parsons had a holistic social theory, Rostow had a quasi Marxist stress on the forces of production (Wheeler, 2005). In accordance with modernization theory, Rostow's (1968) stage's of economic growth stipulates that for Third World countries to develop, they must go through similar historical stages experienced by Western states (also in Dibua, 2006). MDGs are therefore viewed as the path to development for Third World countries.

Some modernization theory proponents contend that it might have some worthwhile core ideas. Wheeler (2005) mentions five modernization policies in China without which the country would have remained stagnant. He notes the transformation of industry, agriculture and science and technology and representative democracy as particularly important in China. Jiafeng (2009) believes that the modern society has not brought the demise of traditional values, rather it has provided tradition with improved status and environment.

Therefore, by defining a singular path to progressive change, the concept of modernization was able to simplify the complicated world historical problems of decolonization and industrialization thereby helping to guide American economic aid and military intervention in post colonial regions. This view is according to (Gilman, 2003) who adds that unfortunately, modernization theory was hopelessly reductionist in its conception of change abroad. The criticisms of modernization theory are worth being noted because they help point out where Africa is lacking in terms of development. Later discussions on MDGs would show that modernization theory is fundamentally conservative in its policies and blindly reflective of the political and social prejudices of mid-century American establishment.

\subsection{Trends in Economic Growth and Social Development in Sub-Saharan Africa}

According to Sachs (1992), the gap between the North and South is growing in spite of the promise of the development discourse. As such stipulating high mass consumption as the end point for all development presents a concern for countries who wish to avoid the social and environmental problems caused by over consumption. Fangjun (2009) asserts that the division of tradition and modernity by modernization theorists such as Rostow was over simplified. It was criticized as being too generalized as modernization of the west was made the criterion for modernization worldwide, thus leaving the transformation of many more countries unexplained. 
This argument corresponds with Rostow's concept of the universality of the process of modernization which has been criticized for its concept and notion of a single, fixed end-stage of development and ethnocentrism (Peet, 1991).

Peet also argues that the developmental history of Euro-America is generalized into a sequence of stages of economic growth which all societies must follow. It is highly unlikely for all Third World countries to repeat the same stages because a global structure has been created by capitalism including a center of power which is in some ways unfavorable to the underdeveloped world. Peet (1991) further criticizes modernization theory by arguing that values, institutions or technologies developed in one society often do not fit other cultures and may actually be dysfunctional for development. It would be better for Third World countries to modify or recreate their own institutions rather than imitate those of the west (ibid). It is no wonder that African countries report high levels of growth and GDP per capita and yet possess the inability to tackle problems such as women empowerment and quality education. Growth in GDP which is supposed to be the centerpiece of development has limited impact on the economic and social development of African countries as depicted in the table and figure below.

Table 1. Sub-Saharan Africa: real GDP growth (percent change)

\begin{tabular}{lllllll}
\hline & $2004-08$ & 2009 & 2010 & 2011 & 2012 & 2013 \\
\hline $\begin{array}{l}\text { Sub-Saharan Africa } \\
\text { (Total) }\end{array}$ & 6.5 & 2.8 & 5.3 & 5.1 & 5.4 & 5.3 \\
Of which: & & & & & & \\
Oil-exporting countries & 8.6 & 5.2 & 6.6 & 6.0 & 7.1 & 6.1 \\
Middle-income countries $^{1}$ & 5.0 & -0.8 & 3.7 & 4.3 & 3.4 & 4.0 \\
Of which: South Africa $^{1}$ & 4.9 & -1.5 & 2.9 & 3.1 & 2.7 & 3.4 \\
Low-income countries $^{1}$ & 7.3 & 5.5 & 6.3 & 5.8 & 5.9 & 5.9 \\
Fragile countries & 3.1 & 2.9 & 3.8 & 1.7 & 6.6 & 5.8 \\
Memo item: & & & & & & \\
World economic growth & 4.6 & -0.6 & 5.3 & 3.9 & 3.5 & 4.1 \\
\hline
\end{tabular}

Source: IMF, (2012) World Economic Indicators Database.

${ }^{1}$ Excluding fragile countries.

Despite a slow world recovery and given the difference in performance among country groups, Sub-Saharan Africa has experienced strong growth (IMF, 2012). In the last decade and particularly in 2011, most of the countries of Sub-Saharan Africa (most especially oil exporters and low income countries) performed better than the rest of the world in terms of growth. The projection for 2012 remains generally encouraging. However, Sub-regional problems that may undermine progress exist such as drought in the Sahel, lingering inflation in Eastern Africa, a sluggish recovery in South Africa, and increasing security tensions in parts of West Africa. While global growth has not been speedy, growth in sub-Saharan Africa has stayed strong, running at 5 percent in 2011 (as shown in Table 1 and Figure 1). The growth trend in Sub-Saharan Africa is expected to approach 51/2 percent in 2012, making the region a better performer than other major regions with the exception of developing countries in Asia. 


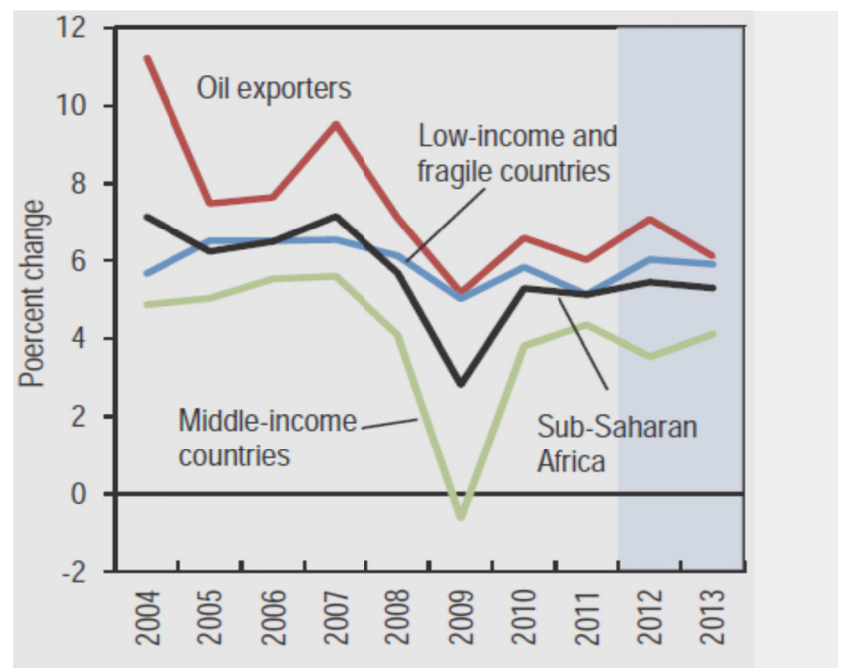

Figure 1. Sub-Saharan Africa: real GDP growth by country group

Source: IMF, World Economic Outlook Database (2012).

According to Cardoso and Faletto (1979), even where development has been occurring, inequality increases as a small minority who are linked to foreign capital monopolizes the benefits of modernization. Gordon (1989) adds that in too many cases, following the west leads to the growing inequality between rich and poor countries rather than to the development of the latter. The same criticism is made about recent developments in Sub-Saharan Africa which are very often linked to GDP and other measures of economic growth. For instance there is rising inequality in countries which have experienced rapid growth between 2000 and 2012 as shown below. The Figure shows that the rise in economic growth in the last decade in Africa has not translated into an improvement in the distribution of income.

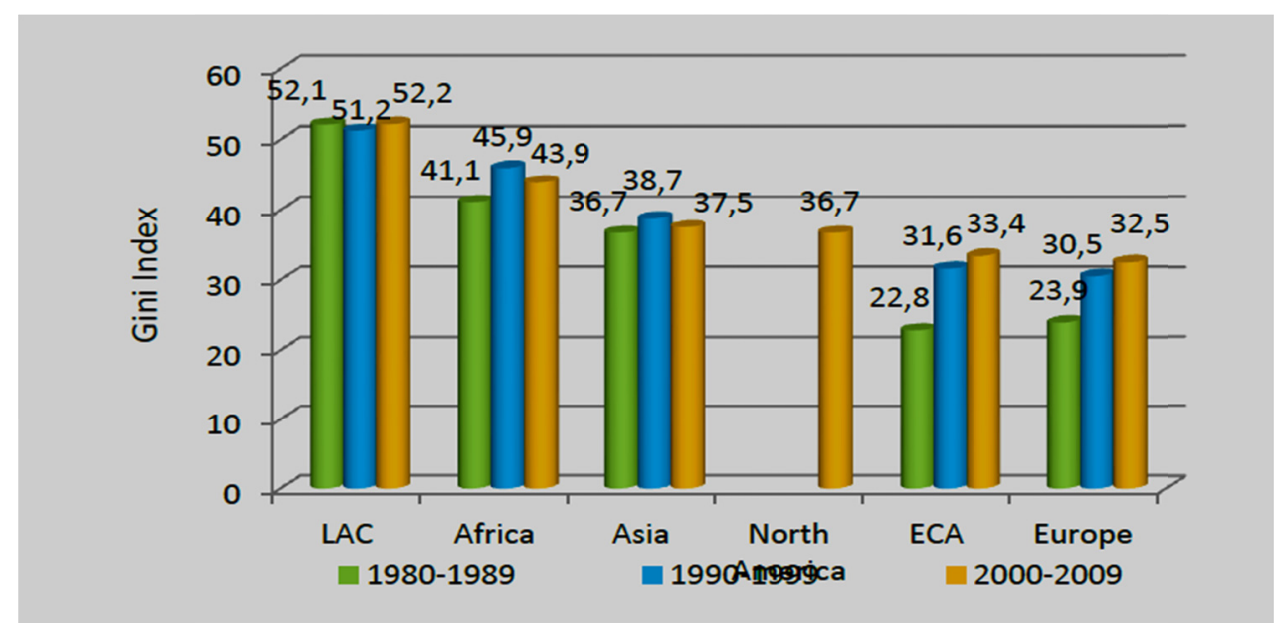

Figure 2. Regional inequalities

Source: World Development Indicators (cited in IMF, 2012) World Economic Outlook Database date.

Based on Figure 2, it is evident that Africa is the world's second most inequitable region after Latin America meaning that inequalities have not diminished over time. In 2010, six out of the 10 most unequal countries worldwide were in Sub-Saharan Africa, and more specifically in Southern Africa. One question arises from these conclusions. Since GDP and other development indices have been growing, why have many of the MDG targets not been reached?

Neo-modernization advocates who refined modernization of the 1960s and 1970s proposed that internal factors such as poor implementation, neo-patrimonialism and corruption should be blamed for non-implementation of 
reform programs in Africa. However, Dibua (2006) finds fault in this argument and states that failure arose from the subordination of African realities to preconceived theories, models and paradigms. The remaining discussions in this paper focus both these ideas using the MDGs as a case in point.

It is evident from Table 2 below that countries with higher quality governance tend to be better performers in growth rates and GDP per capita. Moreover, compared to other countries in Sub-Saharan Africa, these countries are better achievers in terms of MDGs thus exhibiting the lowest maternal mortality rates and highest access to sanitation as well as on the Human Development Index (Penciakova, 2012).

Table 2. Economic and development performance in Sub-Saharan Africa by Governance Tercile

\begin{tabular}{|c|c|c|c|c|c|}
\hline $\begin{array}{l}\text { Quality of } \\
\text { Governanc } \\
\text { e }\end{array}$ & $\begin{array}{l}\text { GDP per capita } \\
\text { growth, } \\
\text { 2005-2010 }\end{array}$ & $\begin{array}{l}\text { GDP per } \\
\text { capita (PPP), } \\
2010\end{array}$ & $\begin{array}{l}\text { Human } \\
\text { Development } \\
\text { Index, 2011 }\end{array}$ & $\begin{array}{l}\text { Maternal Mortality Ratio } \\
\text { (per 100,000 live births), } \\
2005\end{array}$ & $\begin{array}{l}\text { Access to } \\
\text { Sanitation, } \\
2010\end{array}$ \\
\hline Adequate & $3.3 \%$ & 5,606 & 0.52 & 462 & $43.8 \%$ \\
\hline Middling & $2.2 \%$ & 2,264 & 0.43 & 619 & $28.5 \%$ \\
\hline Weak & $1.8 \%$ & 4,184 & 0.40 & 773 & $29.4 \%$ \\
\hline
\end{tabular}

Sources: World Bank, World Development Indicators, 2012; United Nations Development Program, Human Development Report, 2011 (Cited in Penciakova, 2012).

How can African countries achieve the MDGs when the revenues derived from economic growth, are not rightly administered and development policies are poorly implemented? Sachs and Mcarthur (2005) opine that poor governance can also lead to falling short of achieving targets. In such cases of irresponsible governance, countries are fraught with corruption, mismanagement and denial of citizens' equal legal rights and protection. As depicted in Figure 3 below, Sub-Saharan Africa rates poorly on all four governance indicators (government effectiveness, regulatory quality, rule of law, and control of corruption) thus ranking in the bottom third of countries worldwide (Penciakova, 2012).

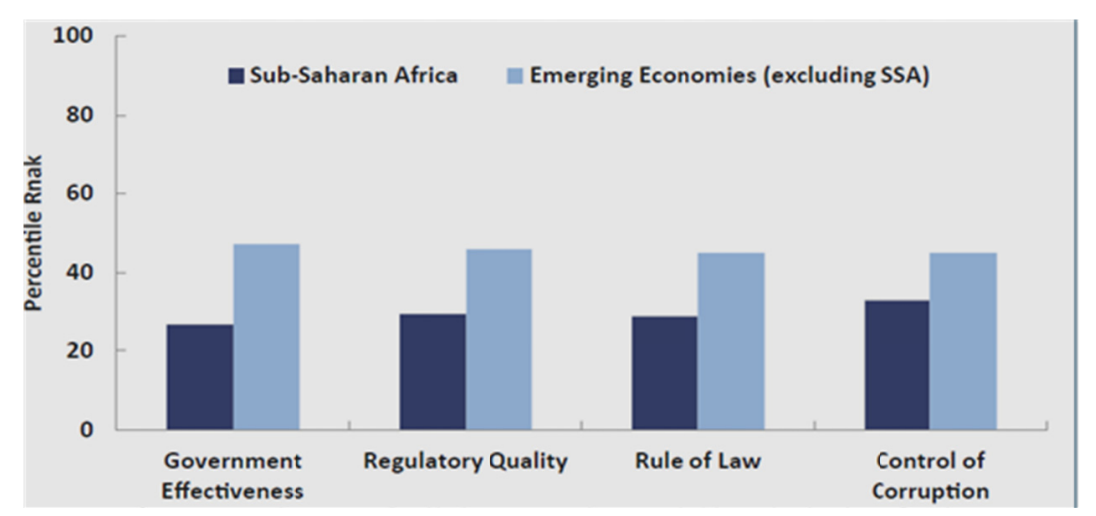

Figure 3. Governance in Sub-Saharan Africa and other emerging economies, 2010

Sources: Kaufmann, D., Kraay, A., \& Mastruzzi, M., "Worldwide Governance Indicators: Methodology and Analytical Issues," October 2011 (Cited in Penciakova, 2012).

Unfortunately, even willing and well intentioned governments are falling short of the MDGs due to problems like lack of human resources and infrastructure. Thus inherent challenges such as vulnerability to financial crisis, conflicts relating to ethnic violence, corruption and political instability hinder the achievement of MDGs. These are discussed in combination with other factors that manifest in the manner in which aid and debt relief are administered, thereby limiting those countries which are more likely to use additional funds to attain their MDG targets. 


\section{Review of Challenges to the Achievement of MDGs}

Goal 1: Eliminating extreme hunger and poverty between 1990 and 2015

This goal is aimed at halving the proportion of people living on less than US\$1 a day and reducing the proportion of people suffering from hunger by half. The UN notes that although gaps in the surveys of Africa's poverty rate are acute, it is very unlikely for Sub-Saharan African countries to achieve the poverty reduction target by 2015 (United Nations, 2010). Estimates by the International Labour Office (ILO) indicate that the rate of extreme working poverty in Sub-Saharan Africa has increased from 57.7 per cent in 2008 to 67.7 per cent in 2010 (ILO, 2010). According to the United Nations (2010) shortfalls in Sub-Saharan Africa reflect slow growth in the 1990s and the transition from planned to market economies that saw poverty increase. The Global economic and financial crisis in 2008 has particularly challenged the poverty reduction goal. It caused a sudden reduction in export and commodity prices thereby reducing trade and investment. Consequently, the crisis slowed growth in developing countries and further increased the number of people engaged in vulnerable employment in 2009 (United Nations, 2010).

Goal 2: Universal primary education

This goal sets out to achieve completion of full course of primary schooling by all children (boys and girls) by 2015. Countries in South Asia and Sub-Saharan Africa are lagging far behind the goal on education. Although enrolment increased by 18 percentage points in Sub-Saharan Africa between 1999 and 2008, the pace of progress is not sufficient to achieve the goal by 2015 (United Nations, 2010). Out of 61 million children who were out of primary school in 2010, about 33 million (more than half of them) were in sub-Saharan Africa (United Nations, 2012). One contributing factor to this trend is that in Sub-Saharan Africa, at least 30 per cent of students attending primary school drop out before they reach final grade (United Nations, 2010). Apart from institutional and management challenges faced by Sub-Saharan African countries, their efforts are also hampered by non transparent spending and investments. In addition, there is lack of commitment to education which is evident in countries' budget allocations and spending on the education sector as well as implementation of their legal and institutional frameworks.

Goal 3: Promoting women empowerment and gender equality

It is noted that the target of eliminating gender disparity in all levels of education is unlikely to be achieved by 2015 (Ngobo cited in Nwonwu, 2008). The Africa Progress Panel (2010) asserts that Africa is far from achieving this goal adding that inability to liberate and harness the energy and skills of women aggravates developmental challenges and restricts progress towards the MDGs. For example the share of women in parliament is only 18 per cent and only one in three paid jobs outside of agriculture are occupied by women in the Sub-Saharan African region. By 2011, the ranking for women's representation in parliaments increased to 20 per cent. This means that the region experienced only small gains since last year despite sustained progress. According to Ojogwu (2009), even in the face of legislation, traditional, cultural and religious factors have effect on women liberation and full access to education.

Goals 4, 5 \& 6: Reducing child mortality, maternal mortality, malaria, HIV/AIDS and TB between 1990 and 2015

The targets set-out in these goals include:

- Reduction of under-five mortality ratio by two-thirds.

- Improving maternal health Reduction of maternal mortality ratio by three-quarters.

- Halting and reversing the spread of HIV/Aids.

- Halting and reversing the incidence of malaria and other major diseases.

While only 12 per cent of the global population lives in Sub-Saharan Africa, 70 per cent of new HIV infections in 2010 were recorded in the region (United Nations, 2012). Africa recorded the highest episodes of malaria in 2010 (about 81 per cent out of 216 million reported cases). Estimates of deaths occurring as a result of malaria in 2010 were 655,000 of which 91 per cent were in Africa (ibid).

Moreover, Sub-Saharan Africa has experienced a 7 per cent decrease in under-5 mortality rate from 1990 (185 per 1000 live births) to 2003 (172 per 1000 live births). The corresponding annual decrease of 0.5 per cent is too low compared to the average rate of 4.3 per cent required per year to achieve the goal by 2015 . However, with this trend, the rate will only decline by 15 per cent in 2015 compared to an expected goal of 66.7 per cent (Fotso et al., 2007). Currently, Sub-Saharan Africa and Oceania have achieved reductions of only around 30 per cent, less than half of what is required to reach the target (United Nations, 2012). 
With a maternal mortality ratio of 500 per 100,000 live births, Sub-Saharan Africa had the highest in developing regions in 2010. 56 per cent of the 287,000 maternal deaths that occurred worldwide were in Sub-Saharan Africa (ibid). The region had a maternal mortality ratio of 500 per 100,000 live births making Sub-Saharan Africa the highest in developing regions. While only 12 per cent of the global population lives in Sub-Saharan Africa, 70 per cent of new HIV infections in 2010 were recorded in the region (ibid).

It is believed that higher rates of maternal, new born and child deaths occur in Sub-Saharan Africa due to unstable and weak health systems especially in conflict riddled countries. For example the conflict riddled Eastern Provinces in Democratic Republic of Congo (DRC) experienced more maternal deaths (1,174 maternal deaths per 100, 000 live births) compared to 811 in the Western region (Coghlan et al., 2006). It is also believed that ineffective health systems and increase in drug resistance tend to affect progress in reducing malaria and the AIDS pandemic in Africa (Sachs, 2004). It is further argued by Holland (2008) that the imprecise nature of this target impedes effective action.

Goal 7: Ensuring environmental sustainability

MDG goal 7 seeks to achieve the following targets:

- Ensuring that the principles of sustainable development are integrated into the policies and programmes of countries, maintain environmental resources and reversing their loss.

- Reducing the proportion of people who have no access to safe drinking water and basic sanitation to half by 2015.

- Achieve significant improvement in the lives of 100 million slum dwellers by 2020 .

The United Nations (2012) MDGs report states that coverage for access to piped water remains very low in sub-Saharan Africa, meaning that the region is not on track to meet the MDG drinking water target by 2015. Over 40 per cent of all people without improved drinking water live in sub-Saharan Africa and compared to other developing regions, Sub-Saharan Africa has made the slowest progress in achieving the sanitation target. This according to Rheingans et al. (2006) is due to population growth or rapid urbanisation, which affects coverage. Also noted is that the local financial and technical resources are insufficient to sustain infrastructure projects in Africa thus obstructing water and sanitation coverage.

Goal 8: Building global partnership for development between 1990 and 2015

The targets set out for achieving this goal include:

- Building trade and financial systems that are open, rule-based, predictable and non-discriminatory.

- Working with Less Developed Countries (LDCs) in order to attend to their special needs.

- Working with landlocked developing countries and small island developing states in order to attend to their special needs.

- Developing national and international measures to address the debt problems of developing countries and in the long term make debt sustainable. In cooperation with developing countries, develop and implement strategies for decent and productive work for youth.

- Collaboration with pharmaceutical companies to make available and improve access to affordable essential drugs in developing countries.

- Collaboration with the private sector to provide access to benefits of new information and communication technologies.

Bilateral aid to sub-Saharan Africa was $\$ 28.0$ billion in 2011, which represents a fall of 0.9 per cent in real terms compared with 2010 (United Nations, 2012). Also, the trade opportunities arising from multilateral liberalization are not utilized by many African countries meaning that they are ill equipped achieve MDG goal 8. (Holland, 2008).

\subsection{Paradox of Economic Growth and Poverty Trends}

The World Bank (2004) suggests that GDP of 7 per cent over 15 years is required to halve poverty rates in Africa but average regional growth is $2.4 \%$ for the past 15 years. Only Botswana and Equatorial Guinea have beaten 7 per cent over this period indicating that the required growth is too high for many countries to reach. This complements Easterly's (2008) view that the MDGs were set up in ways that limited Africa's chances of attaining them in relation to other regions. While various studies have provided insights into the causes of low growth in African countries, authors like Easterly and Levine (1997) contend that the contradiction between 
Africa's growth and poverty incidences remain open to debate.

On the other hand authors like Kanbur (2001) assert that economic growth is required to achieve the poverty reduction goal. However reforms and growth have evidently not led to significant decline of poverty over the years. Estimates by the International Labour Office (ILO) indicate that the rate of extreme working poverty in Sub-Saharan Africa has increased from 57.7 per cent in 2008 to an increase in 67.7 per cent (ILO, 2010). Several studies found that poverty has increased in a number of countries, despite growth in the long run. It can be concluded from this evidence that sustained poverty reduction cannot be guaranteed by increase in economic growth thus raising concerns about the possibility of the poor benefiting from long run growth. In order to achieve pro-poor growth, countries must develop policies that have the potential of increasing growth and reducing poverty simultaneously.

\subsection{The Dilemma in Conflict States}

Having outlined the debate about the relationship between poverty and economic growth using evidence from the most affected regions in Sub-Saharan Africa, it becomes clear that there are other underlying factors responsible for Africa's failure to achieve the MDGs. Jan VandeMoortele (2007) one of the originators of MDGs, adds that the performance of conflict ridden states in meeting their MDG targets is inadequate owing to disruptions in their government institutions, inadequate capacity and uncertainty in the legitimacy of their institutions (Hill et al., 2010). For example hunger is prevalent in countries like Somalia, Sudan and Congo all of which face increasing instability and lack infrastructure (Toronto star, 2010). Stewart (2003) found that during conflicts in some countries, military expenditure may be prioritized to the detriment of social expenditure. For example attention was diverted from MDGs when the Sudanese government failed to deliver most social services to Southern Sudan.

Also, Many African countries have not made progress in satisfying the G8 prerequisite goals for the Highly Indebted Poor Countries (HIPC) initiative because they are faced with internal conflicts. The HIPC itself has been criticised for involving little funds and being limited in scope (Holland, 2008). The IMF (2003) cites that due to the G8 criteria, many countries have been excluded from debt relief despite being equally poor and more indebted than the HIPCs. For example despite Nigeria being the greatest debtor and largest economy in Africa (Holland, 2008), the presence of internal conflict alone can render the country ineligible for debt relief. These and the inability to participate in Global commercial trade hinder Africa's achievement of MDG goal 8.

\subsection{Over-reliance on Aid and Persistence of Poverty}

Some advocates of MDGs agree that more aid is needed by African countries to achieve their targets because a lack of aid has worsened Africa's problems and that there is a link between aid and growth (Taylor, 2006). Clemens et al. (2007) add that leaders in development believe in donor willingness to provide sufficient quantities of funds as a condition for achieving the MDGs. However, regardless of aid increase, many Sub-Saharan African countries will not achieve the MDGs by 2015. This is because African governments do not use their funds efficiently (Clapham, 1996). Another challenge with MDGs is that African countries continue to rely on Official Development Assistance (ODA) from western countries. An argument posed by Clemens (2007) states that increases in aid must be accompanied by other necessary conditions. Where these fail to materialize, those who support aid as a necessary condition for meeting MDGs may be disappointed to find aid being blamed for false failures. This is because donors have no control over other conditions necessary for MDGs to be met such as economic growth and improved policies and institutions (Clemens, 2007). According to Nwonwu (2005) the trend of meeting ODA obligations of developed countries is associated with loss of independence by states, occasioned by dependence on meagre domestic resources and largely on ODA. The latter is often tied to donor benchmarks of conditionalities that may not necessarily tally with the recipient country's objectives and priorities. Toronto Star (2010) reiterates that provision of foreign aid without the necessary political will and functioning institutions results in waste and mismanagement of funds. This paper therefore argues that aid will help in achieving the MDGs but it has to be complemented with policies to reduce violence, root out corruption and increase investment in infrastructure.

Therefore, regardless of increased aid flows, so many countries are not likely to reduce poverty by half given that the required growth will be far too high by historical standards. It is also doubtful that aid will increase growth that would halve poverty in Africa (Clemens et al., 2007). To illustrate, former Nigeria's president Obasanjo's government had a windfall of budget surplus of $\$ 13$ billion between 2003 and 2007. Oil income more than doubled in 2006, meaning that economic pressures were off. However, in the same year, Nigeria had the largest numbers of absolute poor people in the world after China and India, indicating 70 per cent or 84 million people (Dowden, 2008). This outcome can clarify the extent of funds mismanagement in Nigeria. 
According to Dowden (2008) corruption has become such an important part of Nigeria's politics that politicians can be so open about it. Nigeria is the most corrupt country according to transparency international (Dowden, 2008).

Another problem affecting poor countries is that they are simply too poor to invest in programmes that are likely to reduce eliminate diseases and provide adequate infrastructure. As a result, the countries are unable to attain economic growth and subsequently the MDGs. In Sub-Saharan Africa where geographical conditions are not favourable, there is a greater chance of poverty traps occurring. Factors that cause poverty traps include high transport costs, tropical diseases such as malaria and adverse conditions for agriculture such as dependency on rain fed agriculture in sub humid or arid regions (Sachs \& Mcarthur, 2005). In addition, Clapham (1996) asserts that the most important factor underlying the weakness of African states and their vulnerability to internal fragmentation and external penetration is their record of economic failure. According to this author, economic success plays a role in countries' political economy and diplomatic respect while stagnation and decay play a role in their dependence on the uncertain, conditional charity of western donor states and western institutions.

\section{Top-down Approach to MDGs}

In order to illustrate policymaking and Africa's participation in decision-making as it relates to MDGs, Held (cited in Bond, 2004) notes that the MDGs were non- transparently generated by the elite UN agencies. At the same time, the UN agencies, in collaboration with the World Bank, moved to embrace the Washington consensus with its agenda on public private partnership. This indicates a top-down approach to setting and achieving MDG targets. Although the MDGs emerged as a result of consultative processes between the developed and developing countries, they are used as the platform by which western countries assert development policies over African nations. This represents a modernist perspective, which assumes that non-western societies would only attain the stage of being developed if they acquire the instrumental rationalities of western societies (Dibua, 2006). As such, a modernist approach would prescribe the increase in economic growth in order for a country to be developed.

Bond further notes that the institutions, which set the targets, are so far from the people who own the struggles and their victories (Bond, 2004). According to Dibua (2006) development programs, which are in line with modernization theory, have failed to take into account the socio-economic realities of African countries (Dibua, 2006). For example Elson (2004) states that neo-liberal policies imposed by western countries have played a part in and have had adverse impacts on progress towards achievement of the MDGs in Africa.

\subsection{Are the MDGs Attainable?}

Peet and Hartwick (1999) establish the basis for measuring development and their links with the Human Development Index (HDI). In the process, they criticize the measurability of development and the challenges to its measurement. Peetb and Hartwick (1999) argue that official data used to explain economic and socio-cultural characteristics of society are flawed, asserting that they tend to be unreliable and inaccurate. For instance, data for the health MDGs are insufficient and unreliable because even the most basic indicators such as births and deaths are not directly registered in the poorest countries (Attaran, 2005). In addition, GNP or GDP only consider production in the formal market and ignore the informal product consumption and exchange. It is also argued by critics that GNP and GDP measure economic modernization according to how closely countries replicate the characteristics of the west (Peet \& Hartwick, 1999). Nwonwu (2008) highlights the difficulty in assessing performance based on quantitative rather than qualitative yardsticks. He notes the ambiguity of using relative quantities such as ratios that do not portray exact situations. In other words, GDP and GNP are not sufficient for measuring development because they focus on quantity (how many people benefitting and how much gained) rather than quality of life (Peet \& Hartwick, 1999).

In addition, Bond (2006) notes that the restriction of MDG goals to quantifiable indicators is flawed because other important issues such as women's inequality and empowerment may not necessarily be quantifiable. Also, goals including violence against women and sexual and reproductive rights are overlooked. Easterly (2009) opine that all these limitations make MDGs highly unattainable in Africa. Easterly (2009) adds that the MDGs might be intentionally set up by the western countries to portray the universal failure of Africa so as to attract additional attention to foreign aid resources, or even to assert western policies on Africa. As a result, Dibua (2006) cites that even with a constituent level of GDP, the problem of underdevelopment is becoming more intractable. The standard of living of majority of Africans remained unchanged and in some cases worsened. As discussed earlier, it is no wonder that African countries report high levels of growth and GDP per capita and yet possess the inability to achieve the more qualitative targets such as women empowerment and quality education. Therefore, the manner in which MDGs were set up and measured presents fundamental challenges to their achievement. 
It is often argued that the implementation of the MDGs is not on track, and there is no significant progress made by African countries. Despite their challenges, Haines and Cassels (2004) believe that pursuing MDGs is worthwhile because through MDGs, government efforts are geared towards solving development challenges. According to these authors, MDGs also aid governments in assessing their plans, budgets and poverty reduction strategies and point out the need for urgent action by showing how far progress lags behind expectations.

\section{Conclusion and Recommendations}

This paper commenced with a discussion of modernization theory and the link between development and economic growth. It maintained that MDG targets are measured using economic growth indicators. The paper highlighted the challenges encountered in using indicators such as GDP and GNP for measuring progress in development. It argued that despite having firm targets, deadlines and focused urgency, the MDG targets are imprecise and ineffective for development progress. It also argued that some of the targets are so immeasurable that it is difficult to see whether their desired trends of improvement are occurring. The paper indicated that there is a contradictory relationship between modernization and the indigent realities in African countries. The paper acknowledges that by replicating western institutions and experiences as the credible path to development, modernization detracts attention from the crucial roles of culture and the indigenous realities for the development process in developing countries. This shortcoming adversely affects development projects including MDGs. The paper proceeded to argue that the current situation in Africa is that of irresponsible and incapable state authorities. There is rampant violence in which civilians are the most victims. Other challenges that affect the achievement of MDGs include mismanagement of funds, persistence of poverty trap and unhealthy reliance on foreign aid. The western architects of MDGs have failed to realize that African countries need more than 15 years, probably another decade to establish good governance structures, root out corruption and implement democratic, free market models. These would subsequently help in reducing poverty, achieving universal primary education, gender parity, improving health outcomes and increasing participation in global partnership for development. Easterly (2008) maintains that in order to achieve MDGs, there is need for intense efforts by all parties including NGOs and the private sector to actively engage and empower civil society, promote entrepreneurship and the private sector as well as mobilize domestic resources.

Finally, it is necessary to note that substantial increase in aid must be accompanied by MDG based priority investments and global policy reforms including those in trade. Dowden (2008) reinforces the advantages of investment by African countries with an illustration of Nigeria and Indonesia. Both were oil producers which came from similar economic base and corrupt dictatorships. When Suharto left power in 1998, the national output was $\$ 221$ billion after an average 20 year growth rate of 7 per cent. Adult literacy in Indonesia was almost 90 percent and manufacturing represented 40 percent of exports. Nigeria on the other hand had an output of $\$ 33.4$ billion after an average growth rate of 2.5 percent. Adult literacy in Nigeria stood at 60 percent and non oil export was less than 5 percent. The difference is that Indonesia invested in its people and resources. When developing national strategies for poverty reduction and sustainable growth, countries should bear in mind that initial factor endowments differ in each country. Also countries are at different stages of development thus, the development model of a copper rich country with maritime access like Chile should not be imposed on a landlocked country with limited natural resources and capital such as Laos (Roy \& Heuty, 2005).

In concluding this paper, while there are numerous challenges to achieving the MDGs, the weight, importance and type of the challenges depend on the peculiarities of each country. Haines and Cassels (2004) acknowledged that the MDGs are ambitious and that Sub-Saharan African cannot achieve change by simply adopting goals and targets. In addition, the MDGs were set up in such a way that makes Africa very unlikely to achieve them compared to other regions (Easterly, 2008). Africa's challenges to achieving MDGs have more to do with internal challenges such as poor governance and infrastructure than those relating to aid, debt relief and neoliberal policies. The challenge is that aid and debt relief are administered with conditions that many make countries unable access the funds they require thus limiting their achievement of the MDGs. Easterly (2008) asserts that the MDGs are unfair to Africa because all countries have been given the same targets and indicators bearing in mind that African countries started with very high poverty and low GDP rates compared to other more economically stable countries. Countries are at different stages of development for example it would have been easy for a country like China to meet Goal no. 1 (reducing poverty) because they were already on their way to economic prosperity. On the other hand, it would be difficult for a country like Sierra Leone which is just recovering from a war that has devastated the country's economy and infrastructure to achieve goal no.1 even by 2025. This is also a challenge relating to the setting up of the MDGs without considering the different peculiarities of African countries. 


\section{References}

Africa Progress Panel. (2010). From Agenda to action: Turning resources into results for people. Geneva: Africa Progress Panel.

Arabia. (2010). World Bank: Poverty goals still reachable but many falling short. Arabia 2000. Newspaper Source. $\quad$ Retrieved May $18, \quad 2012, \quad$ from http://web.ebscohost.com/ehost/detail?vid=4\&hid=8\&sid=c6707643-a6f4-4bd7-8e74-73820106594e\%40se ssionmgr10\&bdata=JnNpdGU9ZWhvc3QtbGl2ZQ\%3d\%3d\#db=nfh\&AN=6FI2633797377 EBSCOhost

Attaran, A. (2005). An Immeasurable Crisis? A Criticism of the MDGs and why they cannot be Measured. PLOS Medicine, 210, 955-962. http://dx.doi.org/10.1371/journal.pmed.0020318

Birdsall, N., Levine, R., \& Ibrahim, A. (2005). Towards universal primary education: investments, incentives and $\begin{array}{llll}\text { institutions. } \quad \text { European Journal of } & \text { 317-349. }\end{array}$ http://dx.doi.org/10.1111/j.1465-3435.2005.00230.x

Bond, P. (2006). Global Governance Campaigning and MDGs: From Top-Down to Bottom-Up Anti-Poverty Work. Third World Quarterly, 27(2), 339-354. http://dx.doi.org/10.1080/01436590500432622

Clapham, C. (1996). Introduction: Liberalisation, regionalism and statehood in the new development agenda. Third world Quarterly, 17(4), 593-602. http://dx.doi.org/10.1080/01436599615272

Clemens, M. A., Kenny, C. J., \& Moss, T. J. (2007). The trouble with the MDGs: Confronting expectations of aid and development success. World Development, 335-751. http://dx.doi.org/10.1016/j.worlddev.2006.08.003

Coghlan, B., Brennan, R. J., Ngoy, P., Dofara, D., Otto, B., Clements, M., \& Stewart T. (2006). Mortality in the Democratic Republic of Congo: a nationwide survey. Lancet, 367, 44-51. http://dx.doi.org/10.1016/S0140-6736(06)67923-3

Dibua, J. I. (2006). Modernisation and the Crisis of Development in Africa: The Nigerian Experience. Hampshire: Ashgate.

Dowden, R. (2008). Africa: Altered states ordinary miracles. London: Portobello books.

Easterly, W. (2008). How the MDGs are Unfair to Africa. World Development, 37(1), 26-35. http://dx.doi.org/10.1016/j.worlddev.2008.02.009

Elson, D. (2004). The Millennium Development Goals: A Feminist Development Economics Perspective. The Hague: Institute of Social Studies.

Fangjun, C. A. O. (2009). Modernization theory and China's road to modernization. Chinese studies in history, 43(1), 7-16. http://dx.doi.org/10.2753/CSH0009-4633430101

Fotso, J. C., Ezeh, A. C., Madise, N. J., \& Ciera, J. (2007). Progress towards the child mortality millennium development goal in urban Sub-Saharan Africa: The dynamics of population growth, immunization and access to clean water. BioMed Central Public Health, 7(218). http://dx.doi.org/10.1186/1471-2458-7-218

Gilman, N. (2003). Mandarins of the future. Maryland: John Hopkins university press.

Gordon, A. (1989). The myth of modernization and development. Sociological Spectrum, 9(2), 175-195. http://dx.doi.org/10.1080/02732173.1989.9981882

Haines, A., \& Cassels, A. (2004). Education and Debate: Can the MDGs be attained? London: London School of Hygiene and Tropical Medicine and the World Health Organisation.

Hill, P. S., Mansoor, G. F., \& Claudio, F. (2010). Conflict in least-developing countries: challenging the Millennium Development Goals. Bulletin of the World Health Organization, 88(8), 562-562. http://dx.doi.org/10.2471/BLT.09.071365

Holland, M. (2008). The European Union and the global development. European Integration, 30(3), 343-362. http://dx.doi.org/10.1080/07036330802141907

Hulme, D. (2009). The Millennium Development Goals (MDGs): A Short History of the World's Biggest Promise.Imperative. Paris: UNESCO.

IMF. (2012). Regional economic outlook Sub-Saharan Africa: Sustaining growth amid global uncertainty. Washington DC: International Monetary Fund. Retrieved October 8, 2012, from http://www.imf.org/external/pubs/ft/reo/2012/afr/eng/sreo0412.pdf 
IMF. (2003). G-24 Secretariat briefing paper on the Heavily Indebted Poor Country (HIPC) initiative. International Monetary Fund. Retrieved May 11, 2012, from http://www.g24.org/hipc.pdf

International Labour Office. (2010). Global employment trends. Geneva: International Labour Office.

Jiafeng, W. (2009). Some reflections on modernization theory and globalization theory. Chinese studies in history, 43(1), 72-98. http://dx.doi.org/10.2753/CSH0009-4633430107

Kanbur, R. (2001). Economic Policy, Distribution and Poverty: The Nature of Disagreements. World Development, 29(6), 1083-1094. http://dx.doi.org/10.1016/S0305-750X(01)00017-1

Nwonwu, F. (2008). Millennium Development Goals: Achievement and Prospects of meeting the Targets in Africa. Pretoria: Africa Institute of South Africa.

Ojogwu, C. N. (2009). The challenges of attaining Millennium Development Goals in education in Africa by 2015. College Student Journal, 43(2), 375-383.

Peet, R., \& Hartwick, E. (1999). Theories of Development. New York: Guilford.

Peet, R. (1991). Global capitalism: Theories of societal development. Routledge: London \& New York.

Penciakova, V. (2012). Aid, Trade, Investment and Governance in Sub-Saharan Africa: By the Numbers. Paper series on transatlantic trade and development policy issues. Retrieved October 9, 2012, from http://www.scribd.com/doc/99328697/Aid-Trade-Investment-and-Governance-in-Sub-Saharan-Africa-By-th e-Numbers

Rheingans, R., Dreibelbis, R., \& Freeman, M. C. (2006). Beyond the Millennium Development Goals: Public health challenges in water and sanitation. Global Public Health, 1(1), 31-48. http://dx.doi.org/10.1080/17441690500443139

Rostow, W. W. (1968). The Stages of Economic Growth: A Non-Communist Manifesto. Cambridge: Cambridge University Press.

Roy, R., \& Heuty, A. (2005). Investing in development: the Millennium Development Goals, aid and sustainable capital accumulation. Journal of international Affairs, 58(2), 161-175.

Sachs, J. D., \& Mcarthur, J. W. (2005). The Millennium Project: a plan for meeting the Millennium Development Goals. Lancet, 365, 347-353.

Sachs, J. D., McArthur, J. W., Schmidt-Traub, G., Kruk, M., Bahadur, C., Faye, M., \& McCord, G. (2004). Ending Africa's poverty trap. Brookings papers on economic activity, 1, 117-240. http://dx.doi.org/10.1353/eca.2004.0018

Sachs, W. (1992). The Development Dictionary. A Guide to Knowledge as Power. London: Zed Books.

Schuurman, F. J. (2000). Paradigms lost, paradigms regained? Development studies in the twenty first century. Third World quarterly, 21(1), 7-20. http://dx.doi.org/10.1080/01436590013198

Stewart, F. (2003). Conflict and the Millennium Development Goals. Journal of human development, 4(3), 325-339. http://dx.doi.org/10.1080/1464988032000125737

Taylor, I. (2006). The Millennium Development Goals and Africa: Challenges facing the Common wealth. The Round Table, 95(385), 365-382. http://dx.doi.org/10.1080/00358530600748275

Toronto Star. (2010). Will G8 meet its aid pledges? Toronto Star Newspaper Source. Retrieved August 18, 2010, from http://web.ebscohost.com/ehost/detail?vid=1\&hid=8\&sid=89548df6-4867-4f7d-bf29e0727a $86 f 608 \%$ 40sessionmgr10\&bdata $=$ JnNpdGU9ZWhvc3QtbGl2ZQ\%3d\%3d\#db=nfh\&AN=6FP4137670405EBSCOho st

UNDP. (2003). United Nations Development Report. New York: United Nations Development Programme.

UNDP. (2010). United Nations Development Report. New York: United Nations Development Programme.

UNESCO. (2004). EFA Global Monitoring Report 2004. Education for All: The Quality.

United Nations. (2010). Millennium Development Goals. United Nations Summit 20-22 September 2010, New York high level plenary meeting of the general assembly. Retrieved October 8, 2012, from Available at http://www.un.org/millenniumgoals/pdf/MDG_FS_2_EN.pdf

United Nations. (2012). International financial system and development report of the Secretary General. Retrieved October 31, 2012, from http://www.un.org/esa/ffd/documents/67GA_SGR_IFSD_AUV.pdf 
United Nations. (2012). Millennium Development Goals (MDGs) Report. New York: United Nations. Retrieved October 8 , 2012,

from http://www.undp.org/content/dam/undp/library/MDG/english/The_MDG_Report_2012.pdf

Valenzuela, J. S., \& Valenzuela, A. (1978). Modernization and dependency: Alternative perspectives in the study of Latin American underdevelopment. Comparative politics, 10(4), 535-557. http://dx.doi.org/10.2307/421571

Vandamoortele, J. (2009). The MDG conundrum: Missing the targets without missing the point. Development Policy Review, 27(4), 355-371. http://dx.doi.org/10.1111/j.1467-7679.2009.00451.x

WHO. (2010). The African Health Monitor: Achieving the Health MDGs in the African Region. Geneva: World Health Organisation.

Wheeler, N. (2005). Modernization discourse with Chinese characteristics. Humanities, Social Sciences and Law, 22(3), 3-24. http://dx.doi.org/10.1007/s12140-005-0012-8

World Bank. (2004). Global monitoring report: policies and actions for achieving the Millennium Development Goals and related outcomes. Washington: The World Bank. 